\title{
CUSTOMER RELATIONSHIP MANAGEMENT AND FIRM PERFORMANCE: AN EMPIRICAL STUDY OF FREIGHT FORWARDER SERVICES
}

\author{
Kuo-Chung Shang \\ Department of Transportation Science, National Taiwan Ocean University, Taiwan, R.O.C, gordon@mail.ntou.edu.tw \\ Chin-Shan Lu \\ Department of Transportation and Communication Management Science, National Cheng Kung University, Taiwan, \\ R.O.C
}

Follow this and additional works at: https://jmstt.ntou.edu.tw/journal

Part of the Transportation Engineering Commons

\section{Recommended Citation}

Shang, Kuo-Chung and Lu, Chin-Shan (2012) "CUSTOMER RELATIONSHIP MANAGEMENT AND FIRM PERFORMANCE: AN EMPIRICAL STUDY OF FREIGHT FORWARDER SERVICES," Journal of Marine Science and Technology. Vol. 20: Iss. 1, Article 8. DOI: $10.51400 / 2709-6998.2423$

Available at: https://jmstt.ntou.edu.tw/journal/vol20/iss1/8

This Research Article is brought to you for free and open access by Journal of Marine Science and Technology. It has been accepted for inclusion in Journal of Marine Science and Technology by an authorized editor of Journal of Marine Science and Technology. 


\title{
CUSTOMER RELATIONSHIP MANAGEMENT AND FIRM PERFORMANCE: AN EMPIRICAL STUDY OF FREIGHT FORWARDER SERVICES
}

\author{
Kuo-Chung Shang ${ }^{1}$ and Chin-Shan $\mathrm{Lu}^{2}$
}

Key words: customer relationship management (CRM), freight forwarders, structural equation modeling.

\begin{abstract}
This study empirically identifies customer relationship management (CRM) and examines its impacts on firm performance in the context of freight forwarder services. Using data collected from a survey of 144 freight forwarding firms in Taiwan, a structural equation modeling exercise was conducted to identify crucial CRM dimensions and their influences on the perceived financial performance. Results indicated that CRM dimensions such as customer response and profit interaction are found to have significantly positive effects on the perceived financial performance aspects of profit and growth rate.

This research not only investigates crucial CRM but also proposes a model for empirical studies to link CRM and firm performance. To the best of our knowledge, this study is one of the first to examine CRM in the freight forwarder services. The model may be used as a stepping stone for empirical research in transportation services on CRM.

The understanding of relationships between customer response, information technology, knowledge management application, profit interaction, and organizational performance may provide a clue as to how freight forwarding companies can adjust customer relationship creation processes to sustain their performance.
\end{abstract}

\section{INTRODUCTION}

Customer relationship management (CRM) is becoming an important issue in marketing in order to gain customer loyalty, improve customer retention rates [30, 49], as well as increase profits [19]. CRM refers to a management approach that seeks

Paper submitted 05/14/10; revised 08/14/10; accepted 09/24/10. Author for correspondence: Kuo-Chung Shang (e-mail: gordon@mail.ntou.edu.tw).

${ }^{\prime}$ Department of Transportation Science, National Taiwan Ocean University, Taiwan, R.O.C.

${ }^{2}$ Department of Transportation and Communication Management Science, National Cheng Kung University, Taiwan, R.O.C. to create, develop, and enhance relationships with carefully targeted customers in order to maximize customer value and corporate profitability $[4,5,18]$. A majority of research has been limited to examining CRM in a particular service industry, including banking and insurance [46], television entertainment services [35], retailers [17, 49], and financial services companies [12]. Freight forwarder is a particularly customerintensive service sector and links buyers and sellers, creating economic value by effectively delivering products to customers. It plays an important role in delivering a high quality customer service and its performance has linkage with manufacturers'/suppliers' performance [36]. For achieving speed, frequency, and reliability in modern logistics services, freight forwarding firms require instant information and effective CRM for their customers.

A freight forwarder or forwarding agent is a person or company who arranges the carriage of goods and the associated formalities on behalf of a shipper. The duties of a freight forwarder include booking space on a ship, providing all the necessary documentation and arranging customs clearance. Not only are freight forwarders looking less and less different from one another, but a growing range of freight forwarders is providing the same of service. In particular, the freight forwarder industry in Taiwan has become highly competitive. There are nearly 700 freight forwarders in Taiwan and the percentage of foreign firms in this market has consistently remained at a high level [36]. To survive in this dynamic and competitive marketplace, the best way for freight forwarding companies to retain customer loyalty is to provide an environment where customer relationships are effectively managed [49]. Thus, customer relationship management is a critical source of gaining competitive advantage and superior performance in the freight forwarder service sector.

Despite CRM having been found to enhance competitive performance (e.g. [18, 46, 50]), prior studies highlighted the importance of CRM rather than the cause-and-effect relationship between CRM and firm performance [9, 23, 28]. To our knowledge, relatively few empirical studies have examined CRM dimensions in the context of freight forwarder services. It is therefore worthwhile to fill the literature gap by examining the relationship between CRM and firm performance. Accordingly, the purpose of this research is to identify 
key CRM dimensions and examine their influences on organizational performance in the context of freight forwarder services.

There are five sections in this paper. The second section provides a review of the literature on the definition of CRM and dimensions. Section 3 describes the methodological context, including the questionnaire survey, sampling technique, and methods of analysis. Section 4 presents the results and findings of the survey. Conclusions drawn from the analyses and strategic implications for freight forwarding companies are discussed in the final section.

\section{LITERATURE REVIEW AND HYPOTHESES}

CRM refers to the implementation of a specific technology solution project, an integrated series of customer-oriented technology, and a holistic strategic approach to managing customer relationships to create shareholder value [42]. CRM can be defined as a term for methodologies, technologies, and e-commerce capabilities used by companies to manage customer relationships [48], and the management approach that involves identifying, attracting, developing and maintaining successful customer relationships over time in order to increase retention of profitable customers [8, 39].

CRM has also been defined variously as "data-driven marketing" [33]; "a management approach that enables organizations to identify, attract and increase retention of profitable customers by managing relationships with them" [26]; "the development and maintenance of long-term mutually beneficial relationships with strategically significant customers" [10]; and "managerial efforts to manage business interactions with customers by combining business processes and technologies that seek to understand a company's customers" [31]. CRM is proposed as an ongoing process that involves the development and leveraging of market intelligence for the purpose of building and sustaining a profit-maximizing portfolio of customer relationships [51].

A number of critical CRM activities or dimensions have been identified from previous studies. These CRM dimensions include information technology [18, 44, 46], knowledge management application [2], customer communication [17], customer acquisition [22], customer interaction [29, 40, 51], customer response [2, 51], and customer transaction [25]. Specifically, information technology, knowledge management application, customer response, and customer interaction were the most frequently used dimension in the previous studies because together they cover a wide range of CRM activities.

A majority of studies found that information technology was critical for effective customer relationship management $[8,18,46]$. The application of information technology provides abilities for firms to collect and analyze data on customer patterns, interpret customer behavior, develop predictive models, respond with timely and effective customized communications, and deliver product and service value to individual customers [11]. Feinberg and Kadam [18] exam- ined the impacts of e-CRM on customer satisfaction. Results indicated that e-CRM was related to customer satisfaction with a retail site but not to sales and profit. Ryals and Payne [46] revealed the use of information technology in implementing CRM in the financial services sector. They concluded that data warehouses are a powerful tool which managers can use in improving effectiveness and efficiency. Chen and Popovich [11] also pointed out that companies that successfully implement CRM with an integrated technology and process will reap the rewards in customer loyalty and long run profitability. Accordingly, this study hypothesizes that:

$\mathrm{H}_{1}$ : The information technology dimension is positively associated with firm performance in freight forwarder services.

Zablah et al. [51] provided a detailed description of the CRM dimensions which includes knowledge management application and customer interaction management. The knowledge management process refers to a firm's activities that focus on capturing information about customers and markets (e.g., customer response to a direct mail campaign and obtaining data from secondary sources), employing analysis techniques to identify trends and patterns related to customers' behavior and market conditions, and direct contact with the customer [2]. On the other hand, interaction management focuses on the exchange of core benefits (i.e., products and services for money), information exchange, social exchange (i.e., interpersonal exchange), and any combination of the three [29, $40,51]$. Hence, the dimensions of knowledge management application, customer response, and customer interaction, are essential for successfully carrying out CRM which, in turn, enhances organizational performance. Accordingly, this study further hypothesizes that:

$\mathrm{H}_{2}$ : The knowledge management application is positively associated with firm performance in freight forwarder services.

$\mathrm{H}_{3}$ : The customer response is positively associated with firm performance in freight forwarder services.

$\mathrm{H}_{4}$ : The customer interaction management is positively associated with firm performance in freight forwarder services.

\section{RESEARCH METHODOLOGY}

\section{Sample}

The samples for this study primarily focus on the freight forwarders in the Taiwanese market. The population of these firms is drawn from the Members of International Freight Forwarders Association in Taipei, the Republic of China. There were 696 members in the association. A questionnaire survey was sent to all freight forwarding companies. The initial mailing elicited 83 usable responses. A follow up mailing was sent two weeks after the initial mailing, which generated an 


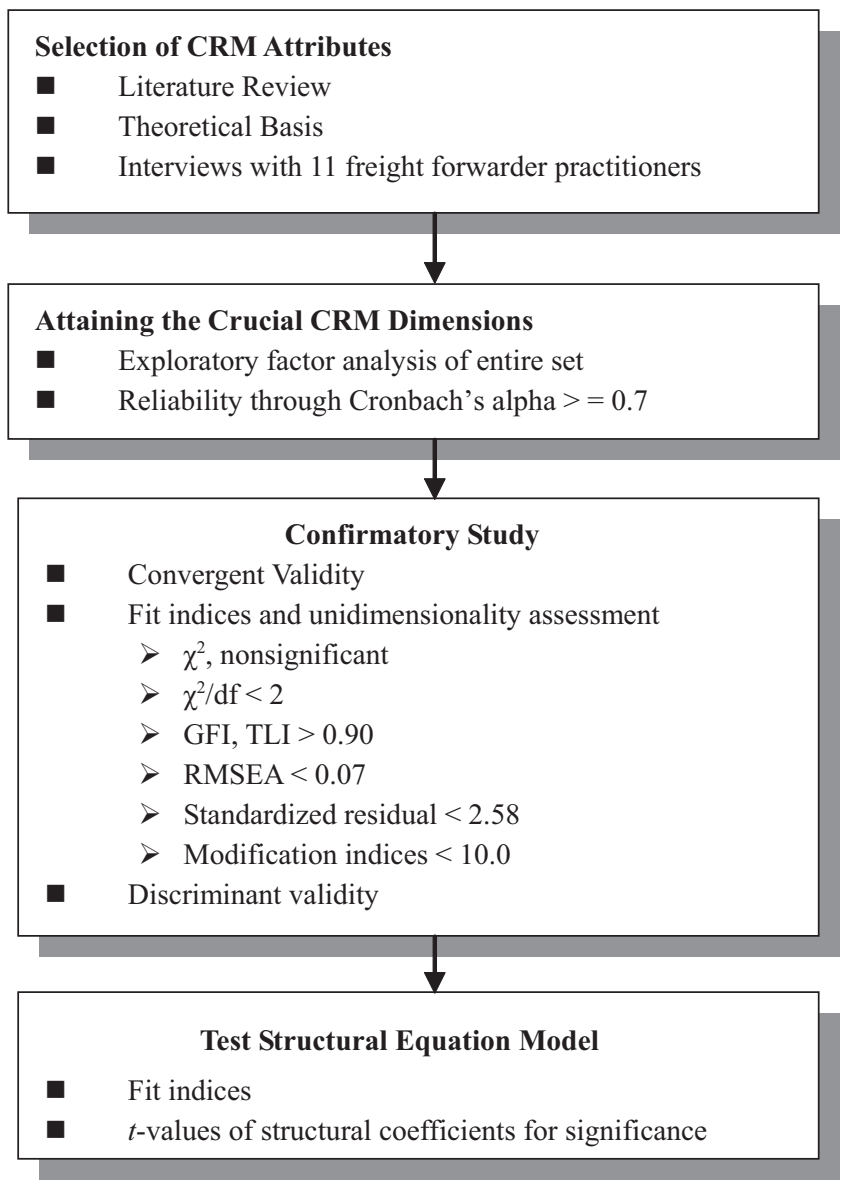

Fig. 1. Analytical steps.

additional 61 usable responses. A total of 144 usable questionnaires were collected, representing $20 \%$ of the target sample. The possibility of non-response bias was checked by comparing early and late respondents' responses for all of the constructs using ANOVA. No significant differences were found [6]. Thus, it was concluded there is no evidence of nonresponse bias.

More than $76 \%$ of respondents were vice president or above or manager/assistant manager. Relatively few respondents were director, general employee, and others (4.4\%, 14.9\%, and $6.0 \%$, respectively). Just over a quarter (30.5\%) had been in operation for more than 20 years, while $29.9 \%$ had been operating between 11 and 20 years. Nearly $20 \%$ of respondents had been operating between 6 and 10 years, while $18.1 \%$ had been operating for less than 5 years. Over three-quarters (78.5\%) of freight forwarder respondents were local companies, while $11.1 \%$ and $10.4 \%$ were foreign companies, and joint venture with local and foreign companies, respectively.

\section{Research Methods}

The research was accomplished by conducting a questionnaire survey. The research steps as shown in Fig. 1 included the questionnaire design and various methods of analysis, described below.
The first step was the selection of CRM and financial performance attributes by reviewing the literature on marketing and management research, followed by the design of the questionnaire, personal interviews with 11 freight forwarder practitioners, and a content validity test. The questionnaire design followed the stages outlined by Churchill [14]. Information sought was first specified, and then the following issues were settled: type of questionnaire and its method of administration, content of individual questions, form of response to and wording of each question, sequence of questions, and physical characteristics of the questionnaire.

In the process of determining questionnaire items, it is crucial to ensure the validity of their content, which is an important measure of a survey instrument's accuracy. Content validity refers to the extent to which a test measures what we actually wish to measure [16]. The assessment of content validity typically involves an organized review of the survey's content to ensure it includes everything it should and does not include anything it should not. It provides a good foundation on which to build a methodologically rigorous assessment of a survey instrument's validity.

Thus, the content validity of the questionnaire in this study was tested through a literature review and interviews with practitioners; in other words, the questions were based on previous studies $[18,29,44,46,51]$ and judged as relevant by 11 freight forwarder executives. Interviews with practitioners resulted in minor modifications to the wording and examples provided in some measurement items, which were finally accepted as possessing content validity. Based on a review of previous literature and personal interviews with freight forwarder practitioners, the measures of CRM and financial performance are shown in Table 1. Respondents were asked to rate them using a five-point Likert scale where ' 1 ' corresponded to 'strongly disagree' and ' 5 ' represented 'strongly agree'.

In the second step, factor analysis was conducted in order to identify and summarize a large number of CRM attributes into a smaller, manageable set of underlying factors, called dimensions. A reliability test was conducted to assess whether these CRM dimensions were adequate. In the third step, the researchers assessed the validity of the measurement model, including unidimensionality, reliability, convergent validity, and discriminant validity, by using confirmatory factor analysis (CFA). Following validation of the measurement model SEM (if appropriate) can be used to estimate the structural model. Analysis was carried out using the SPSS 12.0 (2003) for Windows and AMOS 5.0 (2003) statistical packages.

\section{RESULTS OF EMPIRICAL ANALYSES}

\section{Perceptions of CRM}

In order to evaluate CRM, respondents were asked to rate 20 CRM attributes. The results shown in Table 1 indicate that the four most important attributes (those having a mean score greater than 4.0) of CRM from the perception of the freight 
Table 1. Respondents' perceptions of CRM attributes and perceived financial performance.

\begin{tabular}{|c|c|c|}
\hline No & CRM attributes & Mean S.D. \\
\hline
\end{tabular}

Our company uses phone calls, e-mails, and

C5 personnel visits to communicate with custom- $4.49 \quad 0.81$ ers.

C6 Our company promptly responds to customers' problems, suggestions, and complaints.

C9 Our company actively responds to customers' enquiries of our services

$4.07 \quad 0.94$

Our company actively provides transportation related information to customers.

$4.05 \quad 0.97$

C8 Our company actively understands customers' service requirements and expectations.

C19 Our company provides a variety of service items and information.

Our company's computer system is capable of

C1 storing, searching, and analyzing customers' data.

C15 Our company has flexible measures for customers' urgent requirements.

C16 Our company has different marketing patterns for target customers.

C17 Our company uses customer information to develop a new market.

C13 Our customers often introduce other customers to use our company's services.

C10 Our customers can easily find our company's services related information.

C14 Our company analyzes individual customers' profit contribution.

C20 Our company provides price differentiation for customers.

C18 Our company applies customer information to marketing planning.

C12 Our company actively provides price discount for loyal customers.

C4 Our company has a computer system efficiently to handle customer's information

C2 Our company is capable of using computer system to categorize targeted markets.

Our company's computer system is capable of

C3 organizing and classifying interaction between sale representatives and customers.

C11 Our company sends gifts to customers periodically.

\section{Perceived financial performance attributes}

P1 Our company's profit rate is higher than the average level of the industry.

P2 Our company's growth rate is higher than the average level of the industry.

$3.43 \quad 0.90$

Note: The mean scores are based on a five-point Likert scale $(1=$ strongly disagree to $5=$ strongly agree); S.D. $=$ standard deviation. forwarding firms are: our company uses phone calls, e-mails, and personnel visits to communicate with customers; our company promptly responds to customers' problems, suggestions, and complaints; our company actively responds to customers' enquiries of our services; and our company actively provides transportation-related information to customers. The present study indicates that, when developing their customer relationships, freight forwarding firms need to be especially concerned about their CRM activities to increase their performance and competitive advantage.

\section{Identifying Crucial CRM Dimensions}

Exploratory factor analysis with VARIMAX rotation was employed to identify crucial CRM dimensions in freight forwarder services and an eigenvalue greater than one was used to determine the number of factors [14]. As shown in Table 2, results revealed that three factors accounted for approximately $61.6 \%$ of the total variance and were thus considered to represent all the CRM attributes. To aid interpretation, variables with loadings of 0.4 or greater on only one factor were extracted, which is a conservative criterion based on Hair et al. [24]. Four factors were subsequently found to underlie the CRM sets based on surveyees' responses. They are labeled and described below:

(1) Factor 1, designated customer response dimension, consisted of five items. 'Our company promptly responds to customers' problems, suggestions, and complaints' had the highest factor loading on this factor. Since all these attributes are related to customer response, this factor was called 'customer response' and it accounted for $39.27 \%$ of the total variance.

(2) Factor 2, termed the knowledge management application dimension, consisted of five items. 'Our company has different marketing patterns for target customers' had the highest factor loading on this factor. This factor was identified as 'knowledge management application' and it accounted for $8.67 \%$ of the total variance.

(3) Factor 3, named information technology dimension, comprised five items. 'Our company is capable of using computer system to categorize targeted markets' had the highest factor loading on this factor. All items related to information technology and, hence, this factor was named 'information technology'. It accounted for $7.10 \%$ of the total variance.

(4) Factor 4, termed benefit interaction dimension, consisted of five items. 'Our company actively provides price discount for loyal customers' had the highest factor loading on this factor. All items related to benefit interaction and, therefore, this factor was identified 'benefit interaction' dimensions and it accounted for $6.60 \%$ of the total variance.

\section{Reliability Test}

A reliability test based on Cronbach's Alpha was used to 
Table 2. Results of factor analysis.

\begin{tabular}{|c|c|c|c|c|c|}
\hline No & CRM attributes & Factor 1 & Factor 2 & Factor 3 & Factor 4 \\
\hline C6 & Our company promptly responds to customers' problems, suggestions, and complaints. & $\underline{0.813}$ & 0.153 & 0.276 & 0.019 \\
\hline C5 & Our company uses phone calls, e-mails, and personnel visits to communicate with customers. & $\underline{0.793}$ & 0.133 & 0.144 & 0.133 \\
\hline C9 & Our company actively responds to customers' enquiries of our services. & $\underline{0.703}$ & 0.217 & 0.069 & 0.264 \\
\hline C7 & Our company actively provides transportation related information to customers. & $\underline{0.653}$ & 0.356 & 0.304 & 0.186 \\
\hline $\mathrm{C} 8$ & Our company actively understands customers' service requirements and expectations. & $\underline{0.617}$ & 0.340 & 0.247 & 0.036 \\
\hline $\mathrm{C} 16$ & Our company has different marketing patterns for target customers. & 0.206 & $\underline{0.825}$ & 0.015 & 0.117 \\
\hline $\mathrm{C} 18$ & Our company applies customer information to marketing planning. & 0.060 & $\underline{0.769}$ & 0.230 & 0.226 \\
\hline $\mathrm{C} 17$ & Our company uses customer information to develop a new market. & 0.324 & $\underline{0.739}$ & 0.239 & 0.112 \\
\hline C15 & Our company has flexible measures for customers' urgent requirements. & 0.386 & $\underline{0.688}$ & 0.177 & 0.193 \\
\hline $\mathrm{C} 19$ & Our company provides a variety of service items and information. & 0.451 & $\underline{0.547}$ & 0.319 & 0.129 \\
\hline $\mathrm{C} 2$ & Our company is capable of using computer system to categorize targeted markets. & 0.045 & 0.286 & $\underline{0.781}$ & 0.090 \\
\hline $\mathrm{C} 4$ & Our company has a computer system efficiently to handle customer's information. & 0.197 & 0.044 & $\underline{0.737}$ & 0.119 \\
\hline C3 & $\begin{array}{l}\text { Our company's computer system is capable of organizing and classifying interaction between } \\
\text { sale representatives and customers. }\end{array}$ & 0.156 & 0.221 & $\underline{0.730}$ & 0.044 \\
\hline $\mathrm{C} 1$ & $\begin{array}{l}\text { Our company's computer system is capable of storing, searching, and analyzing customers' } \\
\text { data. }\end{array}$ & 270 & 0.045 & $\underline{0.716}$ & 0.092 \\
\hline $\mathrm{C} 14$ & Our company analyzes individual customers' profit contribution. & 0.334 & 0.369 & $\underline{0.446}$ & 0.055 \\
\hline $\mathrm{C} 12$ & Our company actively provides price discount for loyal customers. & 0.007 & -0.007 & 0.207 & $\underline{0.748}$ \\
\hline $\mathrm{C} 11$ & Our company sends gifts to customers periodically. & 0.052 & 0.181 & 0.280 & $\underline{0.676}$ \\
\hline $\mathrm{C} 13$ & Our customers often introduce other customers to use our company's services. & 0.437 & 0.161 & -0.049 & $\underline{0.580}$ \\
\hline $\mathrm{C} 20$ & Our company provides price differentiation for customers. & 0.144 & 0.183 & -0.130 & $\underline{0.568}$ \\
\hline $\mathrm{C} 10$ & Our customers can easily find our company's services related information. & 0.379 & 0.308 & 0.268 & $\underline{0.417}$ \\
\hline \multicolumn{2}{|c|}{ Eigenvalues } & 7.855 & 1.733 & 1.420 & 1.320 \\
\hline \multicolumn{2}{|c|}{ Percentage variance } & 39.27 & 8.66 & 7.10 & 6.60 \\
\hline
\end{tabular}

Table 3. Cronbach alpha value for each CRM dimension.

\begin{tabular}{lcccc}
\hline CRM dimension & $\begin{array}{c}\text { Number } \\
\text { of items }\end{array}$ & $\begin{array}{c}\text { Cronbach } \\
\text { Alpha }\end{array}$ & Mean & S.D. \\
\hline $\begin{array}{l}\text { 1. Customer response } \\
\text { 2. Knowledge management } \\
\quad \text { application }\end{array}$ & 5 & 0.86 & 4.18 & 0.76 \\
$\begin{array}{l}\text { 3. Information technology } \\
\text { 4. Benefit interaction }\end{array}$ & 5 & 0.87 & 3.69 & 0.78 \\
\hline
\end{tabular}

Note: 1. Represent mean scores based on a five-point scale (1= strongly disagree, $5=$ strongly agree). 2 . Standard deviation.

determine whether the measures of CRM were consistent and reliable. As shown in Table 3, the Cronbach Alpha values of each dimension were all equal to or above the suggested threshold of 0.70 , which was considered adequate for confirming a satisfactory level of reliability in research [14, 41, 47]. Table 3 also shows respondents' agreement level with each CRM in the current situation.

Results showed that the critical CRM dimensions as perceived by respondents were customer response (mean $=4.18$ ), followed by knowledge management application (mean = $3.69)$, benefit interaction (mean $=3.47)$, and information technology $($ mean $=3.46)$.

\section{Discriminant and Convergent Validity}

Before testing the hypotheses, a confirmatory factor using AMOS was performed to ensure the validity of the measurement scale [3]. Results indicated that unidimensionality and convergent validity were satisfactory $[20,32]$ because: $(1)$ the three goodness-of-fit indices (the comparative fit index, $\mathrm{CFI}=$ 0.91 ; the Tucker-Lewis index, TLI $=0.90$; and the root mean square error of approximation, RMSEA $=0.067$ ), satisfied the cutoff criteria [7, 27]; (2) no pair of standardized residual values, which represent 'the differences between the observed correlation or covariance and the estimated correlation or covariance matrix' [24], was greater than \pm 2.58 ; (3) no especially larger modification indices' (MI) values were anticipated to be modified; (4) all expected parameter change (EPC) values were smaller than \pm 0.3 ; (5) all variables, $t$-values were significant ( $t$-values $> \pm 1.96$ ); and (6) all factor loadings $(\lambda)$ on each variable were greater than 0.7 . Discriminant validity, which was assessed using the $\chi_{\text {different }}^{2}$ test to compare the base model (unconstrained) and other pairs of constructs (constrained) [1, 3], was satisfactory because all pairs of latent variables were statistically significant $(p<0.05)$.

\section{CRM and Perceived Financial Performance}

Structural equation modeling (SEM) results are displayed 


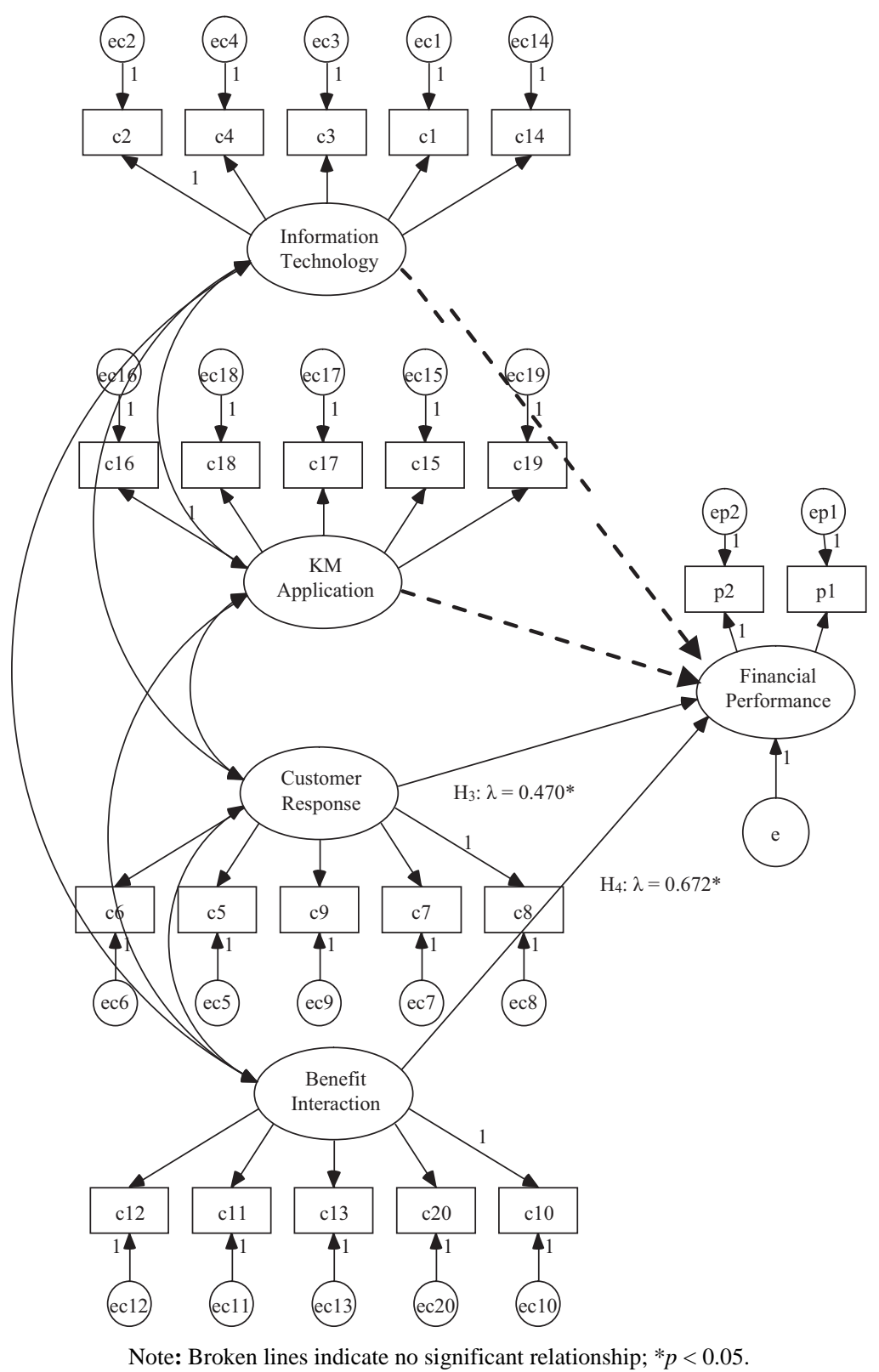

Fig. 2. The research results.

in Fig. 2. The fit indexes were accepted (Chi-square $=323.46$; d.f. $=199, p=0.001 ;$ CFI $=0.91 ;$ TLI $=0.90 ;$ RMSEA $=$ 0.067), implying that this estimated model was a good-fit model. No variables in this model had to be modified because none had sizeable standardized residuals (value $> \pm 2.58$ ), nor especially larger MI and EPC values. To summarize, overall requirements for model identification were satisfied.

Results of the SEM analysis indicated that a positive significant relationship $(\lambda=0.470 t=2.43)$ was found between customer response and perceived financial performance $\left(\mathrm{H}_{3}\right)$. This implies that freight forwarder managers enthusiastically responding to shippers' (customers') problems and understanding customers' service requirements, etc. can improve firm financial performance in the aspects of profit and growth rate. The above findings are consistent with the propositions of previous studies of Alavi and Leidner [2] and Zablah et al. [51].

Results also indicated that benefit interaction had significant positive effects $(\lambda=0.672 ; t=2.20)$ on perceived financial performance in freight forwarder services $\left(\mathrm{H}_{4}\right)$. This implies that freight forwarding companies not only have to promptly meet customers' requirements but provide benefit interaction services such as price discount, gift, and incentives for their customers to retain a long-term customer relationship. The findings are consistent with prior studies on CRM $[29,40,51]$. 
This study expects that knowledge management application $\left(\mathrm{H}_{1}\right)$ and information technology $\left(\mathrm{H}_{2}\right)$ could affect perceived financial performance. However, the results show that the effects of knowledge management application and information technology on perceived financial performance in terms of profit and growth rate were not supported in this study. The knowledge management needs to be based on the application of information technology. This implies that information technology does not support all kinds of organizational performance directly. It is not surprising because information technology is costly for the small and medium size of freight forwarding companies. In addition, although intranet, internet, data warehouse or ERP system can help collaborative work, this technologically facilitated communication cannot replace face-to-face contact for tacit-to-tacit customer services.

\section{DISCUSSION AND CONCLUSIONS}

Customer relationship management has been seen as a crucial organizational capability to enhance competitive advantage [45]. This study has drawn attention to the importance of the relationship between CRM and firm performance in the freight forwarder service context. The main findings of this study based on a survey conducted in Taiwan are summarized below.

The five most important CRM attributes from the perception of the forwarder are use phone calls, e-mails, and personnel visits to communicate with customers; promptly responds to customers' problems, suggestions, and complaints; actively responds to customers' enquires of our services; actively provides transportation related information to customers; and actively understands customers' service requirements and expectations. This is consistent with previous CRM studies on service attributes $[8,40,49]$. The present research indicates that freight forwarders need to be especially concerned about these service attributes when developing their service offerings.

Factor analysis was conducted to classify the identified CRM attributes into four critical service dimensions: customer response, knowledge management application, information technology, and benefit interaction. The results indicate that customer response was the most important CRM service factor, followed by knowledge management application, information technology, and benefit interaction.

A positive significant relationship was found between the customer response and perceived financial performance. This finding suggests that freight forwarding companies should particularly emphasize CRM attributes such as communication with customers, response to customers' problems and complaints, understanding customers' service requirements, and actively responds to customers' enquires of their services in order to increase their competitive edge. The impact of the benefit interaction factor on perceived financial performance was also supported in this study. This suggests benefit interaction factor, including price discount, gifts, and price dif- ferentiation were all critical service attributes for freight forwarding companies to take into account when developing CRM.

However, the influences of the information technology and KM application on firms' financial performance were not supported in this study. Although many previous studies have indicated information technology $[11,18]$ and $\mathrm{KM}$ application $[29,40,51]$ factors influence financial performance, the empirical relationship between these two factors and financial performance is unclear. This is not surprising because the application of information technology is costly for the small and medium size of freight forwarding companies.

Several contributions are drawn from this study. First, despite an awareness of the existence of the notion of CRM for many years, it is only now gaining acceptance as a way of sustaining a competitive advantage in a particular market. However, no empirical study of CRM has been discussed in previous transportation-related service sector. This research not only investigates crucial CRM but also proposes a model for empirical studies to link CRM and firm performance. To the best of our knowledge, this study is one of the first to examine CRM in the freight forwarder services. The model may be used as a stepping stone for empirical research in transportation services on CRM.

Second, from a theoretical perspective, a body of literature has explored the importance of such maritime liner service attributes as transit time, frequency of service, on-time pick-up and delivery, reliability of delivery, ability to provide specialized equipment and requirement, low loss and damage records, and fast response to shippers' requirements to assist management's improvement of service performance $[9,15,36$, 37, 43]. Lu [38] argued the importance of key capabilities in shipping services such as operational capability, customer service, human resource management, information integration, purchasing, and financial management based on the theory of the resource-based view. However, the success of services or operations should depend on the implementation of a CRM, which in turn depends on CRM dimensions such as customer response, information technology, knowledge management application, and profit interaction. This research provides an approach for understanding CRM in the freight forwarder service context.

Third, a practical point of view, the understanding of relationships between customer response, information technology, knowledge management application, profit interaction, and organizational performance may provide a clue as to how freight forwarding companies can adjust customer relationship creation processes to sustain their performance. Freight forwarder managers will be better able to find which dimensions are critical for CRM and, since freight forwarding companies may not manage all modes of customer relationship creation, they may need robust strategies that involve tradeoffs. Finally, this study specifically focuses on the freight forwarding industry. This study's insights into freight forwarder managers' perceived CRM may also be of interest to 
other service industries include airlines, shipping, rail and road operators by providing a useful approach for more effectively evaluating their CRM. The results may also be of value to current and potential freight forwarding companies. The list of CRM attributes may help freight forwarders or other service companies to identify and assess their strengths and weakness in developing customer relationship management.

However, this research would like to point out the various limitations of the study, which provide meaningful directions for future research. First, the data collected on self-reported financial performance and perceptions of CRM in freight forwarder services may have been subject to bias in terms of managers' or general employees' willingness to report and respond. Managers may have been reluctant to report financial performance because of potential personal repercussions and an interest in avoiding lawsuits against the company. Hence, further research could measure financial performance of freight forwarding companies by actual observational method.

Second, this study was limited to four CRM dimensions according to the previous studies of Feinberg and Kadam [18], Peppard [44], Ryals and Payne [46], Alavi and Leidner [2], Kalafatis [29], Metcalf et al. [40], and Zablah et al. [51]. Although these four dimensions are important and by themselves explain CRM, customer relationship management is a complex construct. Future studies should seek to consider CRM enablers such as organizational structure [13] and organizational culture [13, 21, 34]. Finally, this study's findings only reflect the situation regarding CRM at a particular moment in time. Future studies may be conducted using the longitudinal approach to investigate the short- and long-term effects of CRM on service operations.

\section{REFERENCES}

1. Ahire, S. L., Golhar, D. Y., and Waller, M. A., "Development and validation of TQM implementation constructs," Decision Sciences, Vol. 27, No. 1, pp. 23-56 (1996).

2. Alavi, M. and Leidner, D. E., "Review: knowledge management and knowledge management systems: conceptual foundations and research issues," MIS Quarterly, Vol. 25, No. 1, pp. 107-136 (2001).

3. Anderson, J. C. and Gerbing, D. W., "Structural equation modeling in practice: a review and recommended two-step approach," Psychological Bulletin, Vol. 103, No. 3, pp. 411-423 (1988).

4. Anton, J., Customer Relationship Management, Prentice-Hall, New York (1996).

5. Anton, J. and Hoeck, M., E-Business Customer Service, The Anton Press, Santa Monica, CA (2002).

6. Armstrong, J. S. and Overton, T. S., "Estimating non-response bias in mail surveys," Journal of Marketing Research, Vol. 14, No. 3, pp. 396402 (1977).

7. Baumgartner, H. and Homburg, C., "Applications of structural equation modelling in marketing and consumer research: a review," International Journal of Research in Marketing, Vol. 13, No. 2, pp. 139-161(1996).

8. Bradshaw, D. and Brash, C., "Management customer relationships in the e-business world: how to personalize computer relationships for increased profitability," International Journal of Retail \& Distribution Management, Vol. 29, No. 12, pp. 520-530 (2001).

9. Brooks, M. R., "Ocean carrier selection criteria in a new environment," Logistics and Transportation Review, Vol. 26, No. 4, pp. 339-356 (1990).
10. Buttle, F. A., "The CRM value chain," Marketing Business, pp. 52-55 (2001).

11. Chen, I. J. and Popovich, K., "Understanding customer relationship management (CRM): people, process and technology," Business Process Management Journal, Vol. 9, No. 5, pp. 672-688 (2003).

12. Chen, J. S. and Ching, R. K. H., "An empirical study of the relationship of IT intensity and organizational absorptive capacity on CRM performance," Journal of Global Information Management, Vol. 12, No. 1, pp. 117 (2004).

13. Chuang, S. H., "A resource-based perspective on knowledge management capability and competitive advantage: an empirical investigation," Expert Systems with Applications, Vol. 27, No. 3, pp. 459-465 (2004).

14. Churchill, G. A., Marketing Research: Methodological Foundation, 5th ed., The Dryden Press, New York (1991).

15. Collison, F. M., "Market segments for marine liner service," Transportation Journal, Vol. 24, No. 2, pp. 40-54 (1984).

16. Cooper, D. R. and Emory, C. W., Business Research Methods, 5th ed., Irwin, Chicago, IL (1995).

17. Cuthbertson, R. and Laine, A., "The role of CRM within retail loyalty marketing," Journal of Targeting, Measurement and Analysis for Marketing, Vol. 12, No. 3, pp. 290-304 (2004).

18. Feinberg, R. and Kadam, R., "E-CRM web service attributes as determinants of customer satisfaction with retail Web sites," International Journal of Service Industry Management, Vol. 13, No. 5, pp. 432-451 (2002).

19. Fornell, C. and Wernerfelt, B., "Defensive marketing strategy by customer complaint management: a theoretical analysis," Journal of Marketing Research, Vol. 24, No. 4, pp. 337-346 (1987).

20. Garver, M. S. and Mentzer, J. T., "Logistics research methods: employing structural equation modelling to test for construct validity," Journal of Business Logistics, Vol. 20, No. 1, pp. 33-58 (1999).

21. Gold, A. H., Malhotra, A., and Segars, A. H., "Knowledge management: an organizational capabilities perspective," Journal of Management Information Systems, Vol. 18, No. 1, pp. 185-214 (2001).

22. Gouthier, M. and Schmid, S., "Customers and customer relationships in service firms: the perspective of the resource-based view," Marketing Theory, Vol. 3, No. 1, pp. 119-143 (2003).

23. Grewal, D. and Haugstetter, H., "Capturing and sharing knowledge in supply chains in the maritime transport sector: critical issues," Maritime Policy and Management, Vol. 34, No. 2, pp. 169-183 (2007).

24. Hair, J., Anderson, R., Tatham, R., and Black, W., Multivariate Data Analysis with Reading, 5th ed., Prentice Hall International, Upper Saddle River, NJ (1998).

25. Hart, S., Hogg, G., and Banerjee, M., "Does the level of experience have an effect on CRM programs? Exploratory research findings," Industrial Marketing Management, Vol. 33, No. 6, pp. 549-560 (2004).

26. Hobby, J., "Looking after the one who matters," Accountancy Age, Vol. 28, pp. 28-30 (1999).

27. Hu, L. T. and Bentler, P. M., "Cutoff criteria for fit indexes in covariance structure analysis: conventional criteria versus new alternatives," Structural Equation Modeling, Vol. 6, No. 1, pp. 1-31 (1999).

28. Jenssen, J. I., "Innovation, capabilities and competitive advantage in Norwegian shipping," Maritime Policy and Management, Vol. 30, No. 2, pp. 93-106 (2003).

29. Kalafatis, S. P., "Buyer-seller relationships along channels of distribution," Industrial Marketing Management, Vol. 31, No. 3, pp. 215-228 (2002).

30. Kandampully, J., "Service quality to service loyalty: a relationship which goes beyond customer service," Total Quality Management, Vol. 9, No. 6, pp. 431-443 (1998).

31. Kim, J., Suh, E., and Hwang, H., "A model for evaluating the effectiveness of CRM using the balanced scorecard," Journal of Interactive Marketing, Vol. 17, No. 2, pp. 5-19 (2003).

32. Koufteros, X. A., "Testing a model of pull production: a paradigm for manufacturing research using structural equation modelling," Journal of Operations Management, Vol. 17, No. 4, pp. 467-488 (1999). 
33. Kutner, S. and Cripps, J., "Managing the customer portfolio of healthcare enterprises," The Healthcare Forum Journal, Vol. 40, No. 5, pp. 52-54 (1997)

34. Lee, H. and Choi, B., "Knowledge management enablers, processes, and organizational performance: an integrative view and empirical examination," Journal of Management Information Systems, Vol. 20, No. 1, pp. 179-228 (2003).

35. Lemon, K. N., White, T. B., and Winer, R., "Dynamic customer relationship management: incorporating future considerations into the service retention decision," Journal of Marketing, Vol. 66, No. 11, pp. 1-14 (2002)

36. Lu, C. S., "The impact of carrier service attributes on shipper-carrier partnering relationships: a shipper's perspective," Transportation Research - Part E Logistics and Transportation Review, Vol. 39, No. 5, pp. 399-415 (2003).

37. Lu, C. S., "Logistics services in Taiwanese maritime firms," Transportation Research - Part E: Logistics and Transportation Review, Vol. 36, No. 2, pp. 79-96 (2000)

38. Lu, C. S., "Evaluating key resources and capabilities for liner shipping services," Transport Reviews, Vol. 27, No. 3, pp. 285-310 (2007).

39. Massey, A. P., Montoya-Weiss, M., and Holcom, K., "Re-engineering the customer relationships: leveraging knowledge assets at IBM," Decision Support Systems, Vol. 32, No. 2, pp. 155-170 (2001).

40. Metcalf, L. E., Frear, C. R., and Krishnan, R., "Buyer-seller relationships: an application of the IMP interaction Model," European Journal of Marketing, Vol. 26, No. 2, pp. 27-46 (1992).

41. Nunnally, J. C., Psychometric Theory, 2nd ed., McGraw-Hill, New York (1978).

42. Payne, A. and Frow, P., "The role of multichannel integration in customer relationship management," Industrial Marketing Management, Vol. 33, No. 6, pp. 527-538 (2004).

43. Pearson, R., Containerline Performance and Service Quality, University of Liverpool, Marine Transport Center, Liverpool (1980).

44. Peppard, J., "Customer relationship management (CRM) in financial services," European Management Journal, Vol. 18, No. 3, pp. 312-327 (2000).

45. Plakoyiannaki, E. and Tzokas, N., "Customer relationship management: a capabilities portfolio perspective," Journal of Database Marketing \& Customer Strategy Management, Vol. 9, No. 33, pp. 228-237 (2002).

46. Ryals, L. and Payne, A., "Customer relationship management in financial services: towards information-enabled relationship marketing," Journal of Strategic Marketing, Vol. 9, No. 1, pp. 3-27 (2001).

47. Sekaran, U., Research Methods for Business, 2nd ed. John Wiley \& Sons, New York (1992).

48. Stone, M. and Woodcock, N., "Defining CRM and assessing its quality," in: Foss, B. and Stone, M. (Eds.), Successful Customer Relationship Marketing, Kogan, London, pp. 3-20 (2001).

49. Wong, A. and Sohal, A., "A critical incident approach to the examination of customer relationship management in a retail chain: an exploratory study," Qualitative Market Research, Vol. 6, No. 4, pp. 248-262 (2003).

50. Yu, L., "Successful customer relationship management," MIT Sloan Management Review, Vol. 42, No. 4, pp. 18-19 (2001).

51. Zablah, A. R., Bellenger, D. N., and Johnston, W. J., “An evaluation of divergent perspectives on customer relationship management: towards a common understanding of an emerging phenomenon," Industrial Marketing Management, Vol. 33, No. 6, pp. 475-489 (2004). 